\title{
Intra-city Differences in Cardiac Expression of Inflammatory Genes and Inflammasomes in Young Urbanites: A Pilot Study
}

\author{
Rodolfo Villarreal-Calderon', Gary Dale², Ricardo Delgado-Chávez ${ }^{3}$, Ricardo Torres-Jardón ${ }^{4}$, \\ Hongtu Zhu ${ }^{5}$, Lou Herritt' ${ }^{6}$, Angelica Gónzalez-Maciel7, Rafael Reynoso-Robles 7 , Ying Yuan 5 , \\ Jiaping Wang 5 , Edelmira Solorio-López ${ }^{7}$, Humberto Medina-Cortina ${ }^{7}$, and \\ Lilian Calderón-Garcidueñas ${ }^{6,7}$
}

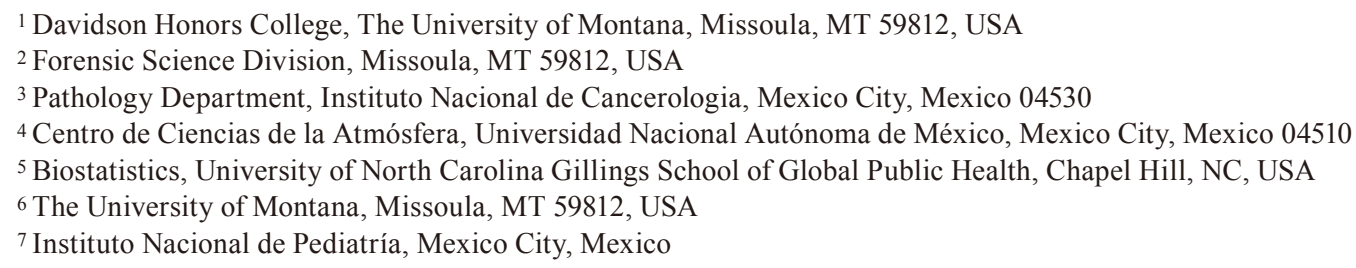

\begin{abstract}
Southwest Mexico City (SWMC) air pollution is characterized by high concentrations of ozone and particulate matter < $10 \mu \mathrm{m}\left(\mathrm{PM}_{10}\right)$ containing lipopolysaccharides while in the North $\mathrm{PM}_{2.5}$ is high. These intra-city differences are likely accounting for higher CD14 and IL-1 $\beta$ in SWMC v NMC mice myocardial expression. This pilot study was designed to investigate whether similar intra-city differences exist in the levels of myocardial inflammatory genes in young people. Inflammatory mediator genes and inflammasome arrays were measured in right and left autopsy ventricles of 6 southwest $/ 15$ north $(18.5 \pm 2.6$ years) $\mathrm{MC}$ residents after fatal sudden accidental deaths. There was a significant $\mathrm{S} v \mathrm{~N}$ right ventricle up-regulation of IL-1 $\beta$ ( $p=0.008)$, TNF- $\alpha(p=0.001)$, IL-10 ( $p=0.001)$, and CD14 ( $p=0.002)$, and a left ventricle difference in TNF- $\alpha(p=0.007)$, and IL-10 ( $p=0.02)$. SW right ventricles had significant up-regulation of NLRC1, NLRP3 and of 29/84 inflammasome genes, including NOD factors and caspases. There was significant degranulation of mast cells both in myocardium and epicardial nerve fibers. Differential expression of key inflammatory myocardial genes and inflammasomes are influenced by the location of residence. Myocardial inflammation and inflammasome activation in young hearts is a plausible pathway of heart injury in urbanites and adverse effects on the cardiovascular system are expected. (DOI: 10.1293/ tox.25.163; J Toxicol Pathol 2012; 25: 163-173)
\end{abstract}

Key words : cardiovascular risk factor, children, particulate matter, inflammasomes, mast cells, myocardial inflammation, urban pollution

\section{Introduction}

Inhalation of particulate matter (PM) air pollution increases the risk for adverse clinical cardiovascular (CV) events as well as both short- and long-term cardiovascular mortality ${ }^{1,2}$. Three generalized intermediary pathways have been hypothesized to explain the detrimental effects on the CV system in response to PM inhalation: pulmonary and systemic oxidative stress and inflammation, pulmonary re-

Received: 29 February 2012, Accepted: 29 March 2012 Mailing address: Lilian Calderón-Garcidueñas, College of Health Professions and Biomedical Sciences, The University of Montana, 32 Campus Drive, 287 Skaggs Bldg, Missoula MT 59812 USA TEL: 1-406-243-4785 FAX: 1-406-243-2807

E-mail: lilian.calderon-garciduenas@umontana.edu (C)2012 The Japanese Society of Toxicologic Pathology

This is an open-access article distributed under the terms of the Creative Commons Attribution Non-Commercial No Derivatives (by-ncnd) License $<$ http://creativecommons.org/licenses/by-nc-nd/3.0/> . ceptor mediated alterations in autonomic balance, and direct effects of PM or its constituents on the vasculature and/ or blood elements after translocation from the lung1. Yet, uncertainty remains whether exposure to different air pollution profiles causes distinct myocardial inflammatory responses in humans.

Residents of Mexico City are exposed year-round to air pollutant concentrations frequently above the National Air Ambient Quality Standards (NAAQS) for the United States ${ }^{3,4}$. High concentrations of fine particulate matter $\left(\mathrm{PM}_{2.5}\right)$ as well as significant levels of PM associated with lipopolysaccharides (PM-LPS) are present in Mexico City's air, and marked regional differences in the air pollutants concentrations and composition have been reported within metropolitan Mexico City ${ }^{3-7}$.

Previously, these well-established regional differences in air pollution between southwest Mexico City (SWMC) and north Mexico City (NMC) were exploited to assess differential health effects in mice exposed for 16 months to 
ambient air8. Tumor necrosis factor- $\alpha$ (TNF- $\alpha$ ), interleukin$1 \beta$ (IL-1 $\beta$ ), and cluster designation antigen 14 (CD14) gene mRNA myocardial expression increased in mice exposed in SWMC when compared to mice from $\mathrm{NMC}^{8}$. The observed differences were attributed to the regional differences in ambient air PM-LPS concentration ${ }^{3-7}$.

The goal for this work was to test the hypothesis that lifetime exposures linked to one of the two distinctly polluted Mexico City target atmospheres modifies the myocardial inflammatory gene profile and inflammasome activation in specimens obtained from autopsied children and young adults with long life residency in the target areas. Given that the pattern recognition Toll-like receptor-4 (TLR-4) is a signaling receptor for lipopolysaccharides (LPS) and that the Asp299Gly TLR-4 polymorphism is associated with a blunted response to lipopolysacharides, we selected individuals with a negative polymorphism ${ }^{9,10}$. Specifically, based on previous in vivo mice studies ${ }^{8}$, myocardial inflammation in SWMC residents exposed to an atmosphere with high concentrations of LPS is predicted to be significantly higher than inflammation in NMC residents. Myocardial mRNA was measured for two key inflammatory genes: IL-1 $\beta$ and TNF- $\alpha$. Measurements were also made of the LPS receptor CD14 and IL-10, an anti-inflammatory cytokine; and two inflammasomes: nucleotide-binding oligomerization domain NOD containing 1 (NLRC1) and pyrin domain containing 3 (NLRP3). A cDNA array targeted for the expression of 84 genes involved in the function of inflammasomes, protein complexes involved in innate immunity and nucleotide oligomerization binding domain (NOD)-like receptors (NLR) signaling was run. Light and electron microscopy of the hearts were also done.

\section{Methods and Procedures}

\section{Study city and air quality}

Mexico City is an example of extreme urban growth and accompanying environmental pollution ${ }^{3,4}$. The metropolitan area of over $2,000 \mathrm{~km}^{2}$ lies in an elevated basin 2,240 meters above sea level surrounded on three sides by mountain ridges. Mexico City's 20 million inhabitants, over 40,000 industries, and 4 million vehicles consume more than 40 million liters of petroleum fuels per day, producing an estimated annual emission of 2.6 tons of particulate and gaseous air pollutants ${ }^{11}$. Mexico City's metropolitan area motor vehicles produce abundant amounts of primary fine PM, elemental carbon, particle-bound polycyclic aromatic hydrocarbons, carbon monoxide, and a wide range of air toxics, including formaldehyde, acetaldehyde, benzene, toluene, and xylenes ${ }^{11-15}$. The high altitude and tropical climate facilitate ozone production all year and contribute to the formation of fine secondary particulate matter. Air quality is generally worse in the winter, when rain is less common and thermal inversions are more frequent. LPS detected in the coarse fraction of PM $\left(\mathrm{PM}_{10}\right)$ from SWMC show the highest LPS concentrations at $59 \mathrm{EU} / \mathrm{mg} \mathrm{PM}_{10} 5,6$. SWMC historically exhibits the highest endotoxin concentrations, with
$\mathrm{PM}_{10}$-LPS ranging from 15.3 to $20.6 \mathrm{ng} / \mathrm{mg}$, while NMC contains less than $70 \%$ of the SW Mexico City values. 5 . On the other hand, ozone concentrations spatial distribution peak towards the downwind SW area in the afternoon as a result of the typical diurnal wind transport of polluted air masses from the urban area. Hourly levels higher than 0.12 ppm as well as 8 -hour ozone average values above 0.075 ppm, the respective US EPA air quality standards, are typically registered in SWMC.

Selection of subjects from SWMC versus NMC was made based on the significant differences between outdoor environments in "northern-industrialized" zones in comparison with "southern-residential" zones, which illustrate the contribution from the industry in the north ${ }^{4,7,13}$. SWMC residents have been exposed to significant concentrations of ozone, secondary tracers $\left(\mathrm{NO}_{3}^{-}\right)$and PM-LPS, while NMC residents have been exposed to higher concentrations of volatile organic compounds (VOCs), $\mathrm{PM}_{2.5}$, and its constituents: organic and elemental carbon including VOCs, secondary inorganic aerosols $\left(\mathrm{SO}_{4}{ }^{2-}, \mathrm{NO}_{3}{ }^{-}, \mathrm{NH}_{4}{ }^{+}\right)$, and metals ( $\mathrm{Zn}, \mathrm{Cu}, \mathrm{Pb}, \mathrm{Ti}, \mathrm{Mn}, \mathrm{Sn}, \mathrm{V}, \mathrm{Ba})^{3,47,15}$. Recent studies on the composition of $\mathrm{PM}_{2.5}$ with regards to sites and samples collected in 1997 show that composition has not changed during the last decade 4 .

\section{Heart samples}

The Human Studies Committees of the involved institutions in Mexico City approved the study and the research protocol. Twenty-one clinically healthy, non-smoking, nonobese children and young adults who died suddenly, accidentally, and without chest or head trauma were included. Six subjects were residents in SWMC and 15 in NMC. Their major everyday activities, including work and school took place within 10 miles of their residency. All subjects had documented instant deaths related to their accidents and were pronounced death at the scene immediately after the accident by the pertinent authorities. Autopsies were performed $3.7 \pm 1.7$ hours after death. Subjects had no pathological evidence of recent or long-term inflammatory processes or pathological findings such as myocardial infarction, valve pathology, coronary artery disease, ventricle or atrial dilatation or hypertrophy, large vessel gross abnormalities, chest trauma, cerebral ischemia, head injury, or stroke. Toxicological studies were negative and included drug alkaline and acid/neutral screen, amphetamines, benzodiazepines, cocaine/opiates, alcohol, volatiles and cannabinoids. All subjects were negative for the Asp299Gly TLR4 polymorphism. The mean age of the SWMC subjects was $19.1 \pm 2.9$ years (mean \pm standard deviation $[\mathrm{SD}]$ ) and $17.8 \pm 2.3$ years for the NMC subjects $(p=0.93)$. Representative sections of the heart muscle including the left and right ventricles and the inter-ventricular septum were fixed in $10 \%$ neutral formaldehyde for 48 hours and transferred to $70 \%$ alcohol for histopathology. Heart tissues were fixed in $2 \%$ paraformaldehyde and $2 \%$ glutaraldehyde in sodium phosphate buffer (0.1 M, pH 7.4) for electron microscopy. The remaining heart tissues were quickly frozen and stored at $-80^{\circ} \mathrm{C}$ and 
transmural sections of the left and right ventricular wall were selected for the RT-PCR and array studies.

\section{Light and electron microscopy}

Paraffin sections $7 \mu \mathrm{m}$ thick were cut and stained with hematoxylin eosin (H\&E) and toluidine blue, and underwent immunohistochemistry for tryptase (Novocastra laboratories Ltd., NCL-MCTRYP 1:50, Newcastle upon Tyne NE12 $8 \mathrm{EW}, \mathrm{UK})$. Three board-certified pathologists (GD, RDC, LCG), including a Forensic pathologist (GD) without access to the identification codes reviewed the sections. Electron microscopy was performed in 8 age-matched cases: 4 NMC and 4 SWMC. Tissues were post-fixed in $1 \%$ osmium tetraoxide and embedded in Epon. Semi-thin sections (0.5 to 1 $\mu \mathrm{m})$ were cut and stained with toluidine blue for light microscopic examination. Ultra-thin sections (60-90 nm) were cut and collected on slot grids previously covered with formvar membrane. Sections were stained with uranyl acetate and lead citrate, and examined with a JEM-1011 (Japan) microscope.

\section{Estimation of mRNA Abundance by RT-PCR}

To determine the expression of mRNA from IL- $1 \beta$, TNF- $\alpha$, IL-10, CD14, NLRC1 and NLRP3, total RNA was extracted from the heart samples using Trizol Reagent (InVitrogen Corp). RNA integrity, concentration, and purity were determined by spectrophotometry using the NanoDrop ND-1000, keeping only samples with the OD A260/A280 and the OD A260/A230 ratios close to 2.0. Small fragments of myocardium, while in ice, were homogenized in $1 \mathrm{~mL}$ of Trizol, and the tissue homogenate was centrifuged at 12,000 $\times \mathrm{g}$ for $15 \mathrm{~min}$ at a temperature of $4^{\circ} \mathrm{C}$. Relative abundances of mRNAs encoding the genes of interest were estimated by quantitative fluorogenic 5' nuclease (TaqMan) assay of the first strand cDNAs using Platinum-qPCR Supermix-UDG reagent (Invitrogen) and the proper oligonucleotide primers and probes.

\section{PCR arrays}

Microarray analysis was conducted with SABiosciences (Frederick, MD, USA) Human Inflammasome Array RT2 Profiler ${ }^{\mathrm{TM}}$. RNA was pooled from each sample inside each group and cDNA was synthesized using the C-03 first strand kit (SABiosciences). Relative gene expression was normalized to five housekeeping genes in each PCR array plate. The fold change for each gene was calculated as $2(\Delta \Delta \mathrm{Ct})$ and shown as up-regulated if expression was $>2$ or down-regulated if expression was $<-2$. Included in the array were 84 genes distributed in three groups: 1) Inflammasomes: i. negative regulation, ii. down-stream signaling, 2) NOD-Like Receptors: i. down-stream signaling, and 3) Pro-inflammatory caspases: CASP1, CASP4, and CASP5.

\section{Statistics}

Statistical analyses were performed using the SAS statistical software 9.0 version. The student's test, the sign test and/or the Wilcoxon signed rank test were used to test whether there were significant differences in the expression of the selected genes and in the difference of the annual $\mathrm{PM}_{2.5}$ between the 2 geographical regions of interest, NMC and SWMC. Significance was assumed at $p<0.05$. Data are expressed as mean values $\pm \mathrm{SD}$.

\section{Results}

\section{Air quality data}

Mexico City residents are exposed year-round to air pollutant concentrations above $\mathrm{PM}_{2.5}$ and ozone United States' National Air Ambient Quality Standards (NAAQS). Panels $1 \mathrm{~A}$ and $1 \mathrm{~B}$ in Fig. 1 show the trend of $\mathrm{PM}_{2.5}$ concentrations from 1997 to 2010 in two representative Metropolitan Mexico City areas located at NMC (Tlalnepantla) and SWMC (Pedregal). The $\mathrm{PM}_{2.5}$ annual air quality standard of $15 \mu \mathrm{g} / \mathrm{m}^{3}$ has been historically exceeded across the metropolitan area, including the selected target areas (Table 1). Statistically higher levels of fine PM have been observed in NMC v SWMC due mostly to industry and heavy truck traffic $(\mathrm{p}=0.0001)$. During the dry season extending from November to May, $\mathrm{PM}_{2.5}$ levels as high as $\sim 90 \mu \mathrm{g} / \mathrm{m}^{3}$ are common in NMC.

\section{Heart histopathology and electron microscopy}

An average of 12 sections were stained and examined for each block, including hematoxilyn-eosin, toluidine blue, Gomori's Trichrome stain, Verhoeff's Elastic Stain, and tryptase. Mild variation in nuclear size in myocardial fibers (Fig. 2A), isolated mononuclear cell infiltrates (Fig. 2B), mast cell degranulation both in myocardium (Fig. 2C), perivascular (Fig. 2D), and in epicardial nerves (Fig. 2E) were observed in all subjects regardless of residency area. Gomori's Trichrome and Verhoeff's elastic stains showed no pathological findings. Particle-like material average size $28 \mathrm{~nm}$ was seen in erythrocytes, endothelial and smooth muscle cells and basement membranes of myocardial arterioles of hearts from NMC and SWMC subjects (2/4 in each group) (Fig. 2F). Tryptase and toluidine blue stained sections provided an assessment of mast cell number. Tryptase positive cells counted per $10 \mathrm{x}$ field yielded $10.8 \pm 2.2$ and $10.03 \pm 3.7$ for SWMC and NMC respectively $(p=0.69)$. For toluidine blue, positive cells counted per $40 \mathrm{x}$ were $1.34 \pm 0.45$ and $0.94 \pm 0.54$ for SWMC and NMC respectively ( $p=0.13)$, and for the percent of degranulated cells using tryptase, we recorded $45 \pm 26$ and $42 \pm 27$ for SWMC and NMC respectively $(p=0.92)$. Thus, no differences were seen between south versus north residents in any of the mast cell endpoints. All participating pathologists concluded that H\&E, Gomori's Trichrome and Verhoeff's elastic stains showed no significant myocardial pathology.

\section{Real-time PCR $m R N A$ analysis of target genes}

Real-time PCR analysis of IL- $1 \beta$, TNF- $\alpha$, IL-10, CD14, NLRC1, and NLRP3 in the heart samples indicated that the corresponding mRNA was present in each of the samples analyzed. Table 2 and Fig. 3 illustrate the RT-PCR results 
Table 1. $\mathrm{PM}_{25}$ Annual Concentrations in $\mu \mathrm{g} / \mathrm{m}^{3}$ for NMC versus SWMC Stations

\begin{tabular}{ccc}
\hline Year & North & South \\
\hline 1997 & 31.84 & 19.51 \\
1998 & 34.66 & 28.31 \\
1999 & 27.45 & 23.59 \\
2000 & 27.48 & 23.93 \\
2001 & 26.49 & 22.94 \\
2002 & 26.49 & 22.48 \\
2003 & 25.68 & 22.84 \\
2004 & 23.81 & 18.36 \\
2005 & 24.26 & 20.78 \\
2006 & 22.19 & 17.68 \\
2007 & 21.83 & 16.85 \\
\hline
\end{tabular}

The differences are significant with a $p=0.0001$.

expressed as an index where the values of the target genes were normalized to the amount of the housekeeping gene, glyceraldehyde-3-phosphate dehydrogenase, (GAPDH) cDNA (expressed in molecules per attomol/GAPDH) for residents of SWMC $\mathrm{v}$ NMC. Up-regulation of IL-1 $\beta$ $(p=0.008)$, TNF- $\alpha(p=0.001)$, IL-10 $(p=0.001)$, and CD14 $(p=0.002)$ was significantly greater in the right ventricle of SWMC v NMC residents. In contrast to the right ventricle, only TNF- $\alpha(p=0.007)$ and IL-10 $(p=0.02)$ where up-regulated in the left ventricle in SWMC v NMC residents.

For the inflammasomes, NLRC1 $(42.6 \pm 18.4$ versus $2.2 \pm 1.7, p=0.0001)$ and NLRP3 (27.4 \pm 0.41 versus $1.1 \pm$ 1.6, $p=0.02)$ were up-regulated significantly in the right ventricle from SWMC $\mathrm{v}$ NMC residents. No differences were measured between SWMC v NMC residents for the left ventricle for either NLRC1 or NLRP3 ( $p=0.5$ and 0.95 , respectively).

\section{Signaling pathways related to inflammasomes}

Myocardial samples from SWMC residents exhibited a significant up-regulation of 29 of 84 genes in the array. The up-regulated genes fell into the following categories: 16 downstream from the NOD-like receptors, 5 inflammasome negative regulation, 5 downstream from inflammasome pathways, two inflammatory caspases, and one NOD-like receptor (Table 3). The four genes with the higher expression were: IRF-1 binding to the upstream regulatory region of type I IFN and IFN-inducible MHC class I genes, CCL-2 (a monocytic and basophil chemotactic factor), CXCL1 (a chemotactic neutrophil factor), and TNF.

\section{Discussion}

Exposures to distinct air pollution environments within Mexico City are associated with significant differences in the expression of key inflammatory and anti-inflammatory cytokines including IL-1 $\beta$, TNF- $\alpha$, IL-10, the LPS receptor CD14 and two key inflammasomes NLRC1 and NLRP3 within the hearts of a unique young autopsy cohort. Specifically, significant differences were observed between SWMC v NMC residents, two areas characterized by sus-
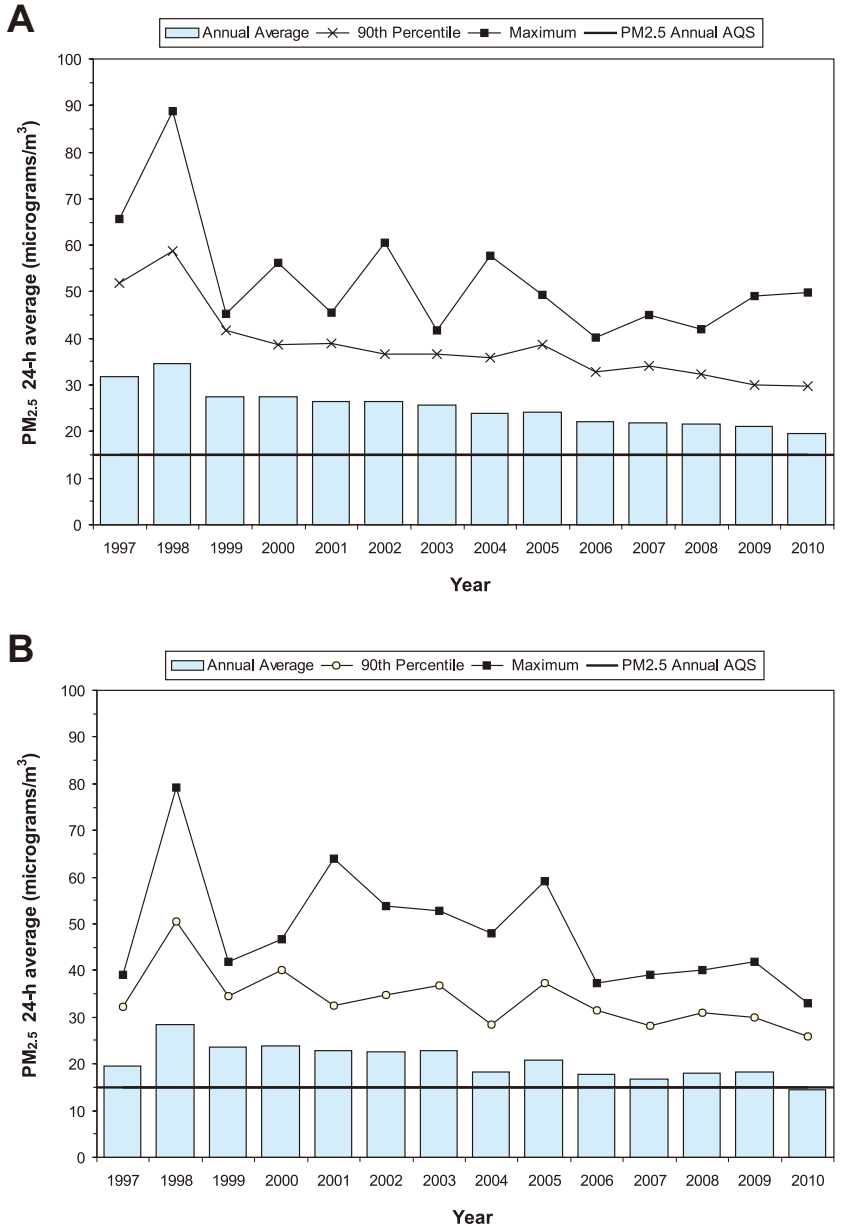

Fig. 1. A: Trends of annual averages, maxima and $90^{\text {th }}$ percentiles of 24-hr $\mathrm{PM}_{2.5}$ levels in the North Mexico City Tlalnepantla (NMC) monitoring station for the period 1997-2010. The levels for the period 1997-2003 were estimated from $\mathrm{PM}_{10}$ data using a regression equation $\left(\mathrm{R}^{2}=0.71\right)$ for simultaneous $\mathrm{PM}_{10}$ and $\mathrm{PM}_{2.5}$ data registered between 2003 and 2007 at the same site. PM data were obtained from the Secretaría del Medio Ambiente, Gobierno del Distrito Federal (SMA-GDF, 2011). $\mathrm{B}$ : Trends of annual averages, maxima and $90^{\text {th }}$ percentiles of 24-hr $\mathrm{PM}_{2.5}$ levels in the Mexico City Southwest Pedregal monitoring station for the period 1997-2010. The levels for the period 1997-2003 were estimated from $\mathrm{PM}_{10}$ data using a regression equation $\left(\mathrm{R}^{2}=0.65\right)$ for simultaneous $\mathrm{PM}_{10}$ and $\mathrm{PM}_{2.5}$ data registered between 2003 and 2007 in the same site. PM data were obtained from the Secretaría del Medio Ambiente, Gobierno del Distrito Federal (SMA-GDF, 2011).

tained differences in the outdoor concentration of PM associated with LPS and in PM 2.5 concentrations. The results suggest a residency effect similar to the one observed in our SWMC v NMC mice studies ${ }^{8}$.

Inflammation involves a coordinated immune response to stimuli related to infections, oxidative stress, or tissue damage ${ }^{16,17}$. The innate immune system rapidly detects invading pathogenic microbes and eliminates them. In the case of SWMC residents PM with LPS likely initiates an inflammatory response having detrimental effects ${ }^{8}$. Toll-like receptors sense "extracellular microbes" (i.e., PM-LPS) and 

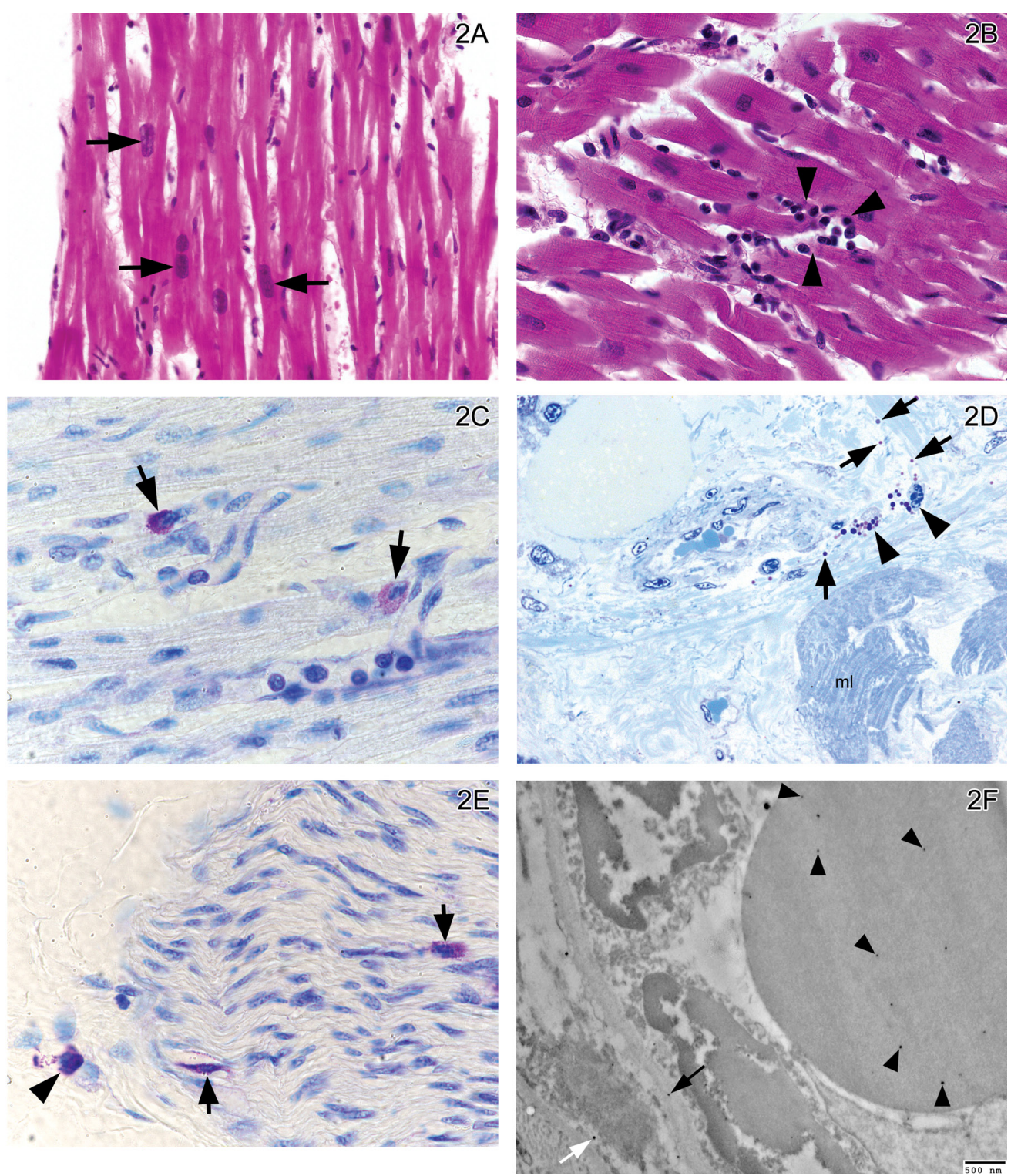

Fig. 2. A: Left ventricle in a 14 year old NMC boy. There is mild variation in the nuclei size of the myocardial fibers (short arrows). H\&E $\times 40$. B: Left ventricle in a 14 year old SWMC girl. Isolated small foci of mononuclear cells are observed (head arrows). $\mathrm{H} \& \mathrm{E} \times 60$. C: Right ventricle in a NMC 11 month old boy. Two mast cells are observed with different degrees of degranulation. The mast cell on the right (short arrow) exhibits significant decrease in the number of cytoplasmic granules. The mast cell on the left is well granulated. Toluidine blue $\times 100$. D: Right ventricle in a 19 year old SWMC male. There are perivascular degranulated mast cells (head arrows). The granules can be observed in the interstitial space (short arrows). Myocardial fibers are labeled mI. Toluidine blue $1 \mu \mathrm{m}$ section $\times 40$. E: Right ventricle epicardial nerve in a 14 year old SWMC girl. There are mast cells located in the epineurial (arrowhead) and endoneurial (short arrows) spaces. Endoneurial mast cells (short arrows) are partially degranulated. Toluidine blue $7 \mu \mathrm{m}$ section $\times 100$. F: Electron micrograph of right ventricle arteriole in a SWMC 19 years old male. The luminal red blood cell (RBC) shows several nanosize particle-like material (average size $28 \mathrm{~nm}$ ) (head arrows) and similar size particulate-like material is seen in the endothelial basement membrane (long arrow), and the smooth muscle cell nucleus and cytoplasm (white arrow). EM $\times 20,000$.

trigger anti-pathogen signaling cascades ${ }^{17}$. Heart tissues require up-regulation of several inflammasome components in order to assemble functional inflammasomes. Although the issue of myocardial inflammasomes has not yet been discussed in air pollution-related human cardiotoxicity, the finding of increased IL-1 $\beta$, CD14, NLRC1 and NLRP3 strongly suggests that inflammasome activation plays a role in exposed subjects.

Up-regulation of two key NOD-like receptor (NLR) family members in the right ventricles from clinically 

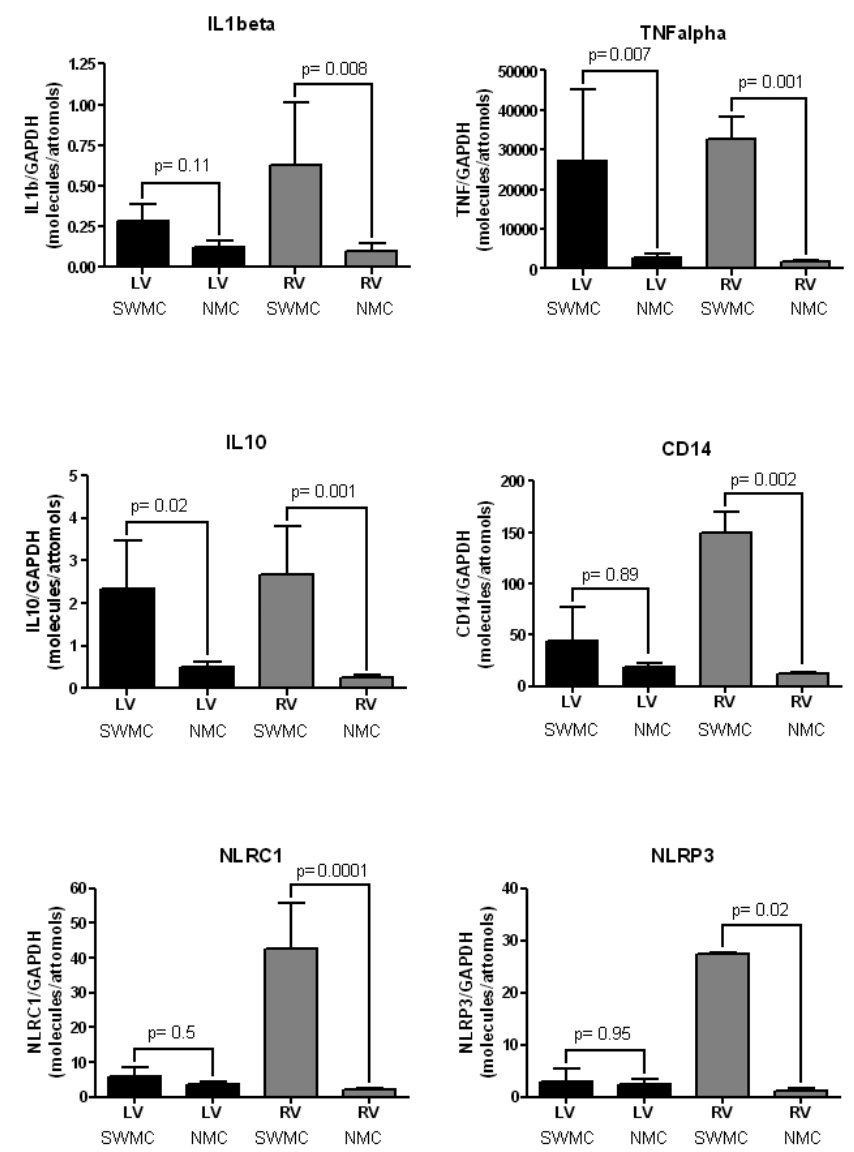

Fig. 3. RT-PCR left and right ventricular mRNA statistical results for IL1 $\beta$, TNF $\alpha$, IL10, CD14, NLCR1 and NLRP3 in SWMC and NMC subjects.

healthy children and young adults is critical in the context of air pollution exposures. NLRC1 enhances caspase-9-mediated apoptosis, induces NF-kappa-B activity via RIPK2 and IKK-gamma and confers responsiveness to intracellular bacterial LPS, while NLRP3 functions as an upstream activator of NF-kappa-B signaling and activates caspase-1 in response to a number of triggers including LPS which leads to processing and release of IL1 $\beta^{16,17}$. The central role of the NLR family as pathogen sensors and activators of inflammatory caspases and transcriptional regulation of immune response genes ${ }^{17-20}$, including pro-inflammatory cytokines with detrimental cardiac effects, raises the issue of the longterm impact of the innate immune altered responses and inflammation upon the cardiovascular system of highly exposed young individuals.

Exposures to micro-particles, including asbestos and silica, activate the NALP3 inflammasome, and NALP3 deficient mice have decreased lung inflammatory responses ${ }^{21-23}$. Cholesterol crystals acting as an endogenous danger signal activate NLRP3 inflammasomes in a mice atherogenesis model $^{24}$. NLRP3/NALP3 activators produce reactive oxygen species (ROS) and are essential secondary messengers signaling inflammasome activation ${ }^{18}$. Thus, inflammasomes are rapidly emerging in air pollution related mechanisms as novel and important cellular complexes involved in inflammatory responses.

As expected, based on the higher historical south Mexico City exposures to endotoxins, the mRNA expression of CD14 was significantly higher in SWMC residents and the right ventricle was the target of the up-regulation. Indeed, the right ventricle expression of the target genes was significantly different for all selected genes, while the left ventricle differences between cohorts were only significant for TNF- $\alpha$ and IL-10. Cardiac chambers differ in their morphologic and contractile properties ${ }^{25}$ and in myocardial circulation $^{26}$. In a heart with increased afterload there is a sharp arterial plethora of the left ventricle and sharp blood stasis in the microcirculatory bed in case of increased right ventricle afterload ${ }^{26}$. These contractile and microcirculatory changes might contribute to the sharp differences between ventricular gene expression in subjects exposed to high levels of pollution. Moreover, PM exposure increases pulmonary arterial pressure related to the production of endothelin-1 (ET1) $27-33$, thus right ventricular pressure-overload potentially could modify the targeted genes responses. The issue is key for young urban residents, as we have seen sustained elevations of ET-1 and pulmonary arterial pressures in clinically healthy children in Mexico City ${ }^{32}$. To complicate matters further, the vasoconstrictor responses upon LPS administration are associated to ET-1 production ${ }^{34}$.

Degranulation of mast cells was observed in the epicardial left and right ventricle nerve bundles. Because portions of autonomic nerves and receptors are located on the epicardial surface of the heart ${ }^{35-38}$, it is possible that the mast cell degranulation may alter autonomic neurotransmission ${ }^{39}$ providing a potential mechanism by which the nervous system impacts on inflammatory ventricular responses. Mast cells had been largely neglected and remain as low key players in the air pollution literature, however there are significant associations between ET-1 and cardiac mast cell degranulation $^{30}$, their role limiting ET-1 toxicity 40,41 and modulation of cardiac contractility through both ET-1 and myocardial mast cell degranulation ${ }^{42}$. Our canine studies in Mexico City versus controls from low polluted areas showed apoptotic myocytes and degranulated mast cells associated with scattered foci of mononuclear cells in both ventricles and the interventricular septum ${ }^{43}$. Thus, the potential inflammatory and physiopathological impact of the mast cell degranulation both in the myocardium and epicardial nerves are critical.

We have shown in young Mexico City residents, a distinct right versus left inflammatory response of the carotid portion of the vagus nerve, specifically the right vagus has a marked up-regulation of COX-244. The role of the right vagus nerve in the innervation of key structures (i.e., liver and bowel) involved in the detoxification and clearance of foreign and altered-self substances including PM and PM-LPS was discussed. Thus, the cardiac vagal innervation could also play a role in the differential ventricular responses ${ }^{44}$.

Pro-inflammatory mediators, such as TNF- $\alpha$ and IL- $1 \beta$ have been implicated in the pathogenesis of myocardial dys- 
Table 2. RT-PCR Results of Target Genes Normalized to the Amount of GADPH cDNA for SWMC and NMC Subjects

\begin{tabular}{|c|c|c|c|c|c|c|}
\hline \multirow{2}{*}{ MC Groups } & \multicolumn{2}{|c|}{ IL-1 $\beta$} & \multicolumn{2}{|c|}{ TNF- $\alpha$} & \multicolumn{2}{|c|}{ IL-10 } \\
\hline & LV & RV & LV & RV & LV & RV \\
\hline SWMC (n: 6) & $0.28 \pm 0.10$ & $0.63 \pm 0.38$ & $27277 \pm 17842$ & $32777 \pm 5567$ & $2.3 \pm 1.14$ & $2.6 \pm 1.15$ \\
\hline \multirow[t]{3}{*}{ NMC (n: 15) } & $0.12 \pm 0.04$ & $0.10 \pm 0.04$ & $2806 \pm 1048$ & $1655 \pm 616$ & $0.48 \pm 0.13$ & $0.25 \pm 0.06$ \\
\hline & \multicolumn{2}{|c|}{ CD14 } & \multicolumn{2}{|c|}{ NLRC1 } & \multicolumn{2}{|c|}{ NLRP3 } \\
\hline & LV & RV & LV & RV & LV & RV \\
\hline SWMC (n: 6) & $43.8 \pm 32.9$ & $150 \pm 20.4$ & $5.7 \pm 5.1$ & $42.6 \pm 18.4$ & $2.9 \pm 4.7$ & $27.4 \pm 0.41$ \\
\hline NMC (n: 15) & $18.92 \pm 3.1$ & $11.86 \pm 2.0$ & $3.6 \pm 3.1$ & $2.1 \pm 1.7$ & $2.4 \pm 3.3$ & $1.1 \pm 1.6$ \\
\hline
\end{tabular}

Table 3. Inflammasomes Signaling Pathway Genes Up-regulated in Myocardial SWMC versus NMC Samples

\begin{tabular}{llc}
\hline \multicolumn{1}{c}{ Symbol } & \multicolumn{1}{c}{ Gene name } & Fold-up regulation \\
\hline IRF1 & interferon regulatory factor 1 & 15.54 \\
CCL-2 & chemokine (C-C motif) ligand 2 & 13.44 \\
CXCL1 & chemokine (C-X-C motif) ligand 1 (melanoma growth stimulating activity, alpha) & 12.19 \\
TNF & tumor necrosis factor & 11.14 \\
BCL2L1 & bcl-2-like protein & 10.40 \\
IRF2 & interferon regulatory factor 2 & 9.18 \\
RAGE & renal cell carcinoma antigen & 8.74 \\
NFKBIA & nuclear factor of kappa light polypeptide gene enhancer in B-cells inhibitor, alpha & 8.33 \\
IL6 & interleukin 6 & 7.51 \\
MAPK13 & mitogen-activated protein kinase 13 & 7.05 \\
PSTPIP1 & proline-serine-threonine phosphatase interacting protein 1 & 6.86 \\
IL12A & interleukin 12A & 6.86 \\
RELA & v-rel reticuloendotheliosis viral oncogene homolog A (avian) & 6.27 \\
IRAK1 & interleukin-1 receptor-associated kinase 1 & 5.85 \\
PTGS2 & cyclooxygenase-2 & 5.49 \\
TNFSF14 & tumor necrosis factor (ligand) superfamily, member 14 & 5.38 \\
BIRC3 & baculoviral IAP repeat-containing 3 & 5.38 \\
MAPK12 & mitogen-activated protein kinase 12 & 5.20 \\
CASP1 & caspase 1 & 4.56 \\
NLRC5 & NLR family, CARD domain containing 5 & 4.37 \\
IKBKG & inhibitor of kappa light polypeptide gene enhancer in B-cells & 3.86 \\
MAP3K7 & mitogen-activated protein kinase kinase kinase 7 & 3.03 \\
CTSB & amyloid precursor protein secretase & 2.94 \\
MAPK8 & mitogen-activated protein kinase 8 & 2.90 \\
CASP4 & Caspase 4 & 2.67 \\
MAPK1 & mitogen-activated protein kinase 1 & 2.75 \\
CFLAR & CASP8 and FADD-like apoptosis regulator & 2.44 \\
NLRC4 & NLR family, CARD domain containing 4 & 2.38 \\
NFKB1 & nuclear factor of kappa light polypeptide gene enhancer in B-cells 1 & 2.11 \\
\hline & & \multicolumn{1}{c}{. } \\
\hline
\end{tabular}

function and cardiomyocyte death in ischemia-reperfusion injury, sepsis, chronic heart failure, viral myocarditis, and cardiac allograft rejection ${ }^{45-47}$. TNF- $\alpha$ was strongly up-regulated in SWMC exposed residents $(p=0.001)$. The importance of TNF in cardiovascular morbidity and mortality is well known 46,47 . In a healthy heart TNF- $\alpha$ is mainly located in the endothelium and in resident mast cells ${ }^{47}$. Apoptosis, inflammation and oxidative stress are pivotal TNF-mediated responses that are independently linked to pathological remodeling 46 . During myocardial ischemia and after myocardial infarction (MI), preformed TNF- $\alpha$ is released within minutes and contributes both to contractile dysfunction and irreversible myocardial injury ${ }^{47}$. Interestingly, preconditioning with TNF- $\alpha$ decreases infarct size ${ }^{48}$. The issue of TNF- $\alpha$ cardioprotective properties depends on a number of factors, including its concentration, the localization of the increased TNF- $\alpha$ levels, the concentrations of the TNF re- ceptors, particularly TNFR1, and the myocardial duration of exposures to detrimental factors ${ }^{47}$. In an infarcted myocardium, TNF- $\alpha$ contributes to cardiomyocyte apoptosis, whereas in the peri-infarct area could stimulate fibroblasts, stabilize the infarcted area and attract stem cells for cardiac repair and decrease inflammation ${ }^{49,50}$. Given that TNF- $\alpha$ has an ambivalent role in case of myocardial infarction and that sustained post-infarction TNF- $\alpha$ contributes to chronic left ventricular dysfunction, it was concluded that myocardial TNF- $\alpha$ biventricular up-regulation in the context of severe exposures to air pollution is not beneficial to the exposed subjects.

The higher level of CD14 mRNA in SWMC residents who are exposed to a higher dose of LPS-PM is a novel and potentially important observation. CD14 is a surface differentiation antigen capable of binding LPS ${ }^{51}$ and the high expression seen in SWMC subjects is likely related to the high 
concentrations of LPS detected in south Mexico City $\mathrm{PM}_{10}$ samples ${ }^{5,6,14}$. The toxic effects of LPS include the release of cytokines, nitric oxide, and reactive oxygen species (ROS) by vascular endothelial cells ${ }^{52,53}$. LPS-induced cardiac dysfunction may be in part due to reactive oxygen species mediated by inflammatory mediators like TNF- $\alpha^{53,54}$. LPS acts through the CD14 receptor to release TNF- $\alpha$, deregulates the intracellular calcium, and gives rise to the apoptotic death program ${ }^{55}$. LPS internalization depends on CD14, as shown in Panaro et al. in an in vitro model of myocardial cells exposed to endotoxin ${ }^{51}$.

The production of pro-inflammatory mediators occurs in the myocardium exposed to endotoxin, a situation that is critical in septic patients. In a model of low-grade chronic inflammation with the administration of low doses of LPS, there was a significant increase in myocardial fibrosis, infiltration of mononuclear cells, and changes in arteries and arterioles, a finding consistent with vascular disease ${ }^{56}$. Given that SWMC residents are exposed to high concentrations of PM-LPS, the observation of their significant up-regulation of CD14, TNF- $\alpha$ and IL-1 $\beta$ suggests a key role of environmental endotoxin on the health of the southern Mexico City population. The issue is key for the understanding of how the sensing of "microbial invaders" (i.e., PM-LPS) could translate into signaling pathways that culminate in the transcriptional regulation of immune responsive genes and how the activation of inflammasomes ${ }^{17,19,57}$ could be a contributing factor for myocardial cardiotoxicity 58 .

Thus, this study's observations in SWMC young adults are potentially important for elderly SWMC residents due to the fact that IL-1 $\beta$ reduces cardiac muscle function and inhibits angiogenesis in cardiac endothelial cells ${ }^{59}$. An increase in myocardial IL-1 $\beta$ could translate in a reduced capacity for proliferation of microvascular endothelial cells and a consequent fault in the myocardial repair after a myocardial infarction. IL-1 $\beta$ is also important to myocardial remodeling ${ }^{60}$, and its increased levels are associated with worsening of interstitial fibrosis ${ }^{61}$. The roles of IL- $1 \beta$ in atherothrombotic disease and after myocardial infarction when it critically regulates the inflammatory response ${ }^{62}$ are also potentially clinically important for SWMC residents.

Chronic inflammation leads to an increase in cardiovascular disease risk 1 . The findings of significant differences in up-regulation of key inflammatory myocardial genes and inflammasomes in healthy young adults provide potential important mechanistic pathways to explain the higher risk of cardiovascular disease in susceptible urban populations. These findings are relevant to susceptible residents in the study areas, since the outcome of cardiac ischemic events depends not only on the intensity and duration of the ischemic stimulus but also on the myocardial intrinsic tolerance to ischemic injury58, even in the absence of manifest cardiovascular disease. Thus, the concept of occult cardiotoxicity as described by Golomb et al. should be taken into account in subjects exposed to significant concentrations of air pollutants.

We recognized that given our strict inclusion criteria including the negative Asp299Gly TLR4 polymorphism, the autopsy time restricted to $3.7 \pm 1.7$ hours after death, and the age range of the subjects, the group is small, however the endpoint results are significantly different to warrant that residency likely plays a key factor in the myocardial responses. Additional characterization of the particle-like material observed in blood vessels by energy filtered TEM ${ }^{63}$ would have benefited these studies.

In summary, exposure to air pollution produces differential up-regulation of key inflammatory genes in young urban residents. Extensive degranulation of mast cells complete the picture in seemingly healthy hearts from children and young adults. Exposure to particulate matter can trigger cardiovascular disease ${ }^{64}$ and long exposures increase the risk for cardiovascular mortality and reduces life expectan$\mathrm{cy}^{1}$, thus our findings of myocardial inflammation in young urbanites may have deleterious $\mathrm{CV}$ effects, especially in view of our reports that sustained endothelin-1 increases are associated with elevated mean pulmonary artery pressure in clinically Mexico City healthy children ${ }^{32}$.

Hopefully this research will contribute: i) to awareness that within-city sustained exposures to a distinct profile of air pollutants produce differential responses in myocardial gene expression, thus the clinical outcomes of cardiac events could be different ii) sustained myocardial up-regulation of IL-1 $\beta$ and TNF- $\alpha$, fundamental in the pathogenesis of myocardial dysfunction, ventricular remodeling, and angiogenesis in cardiac endothelial cells - among their other roles-likely will have long term cardiovascular effects on the exposed populations, iii) occult cardiotoxicity is an important concept in the context of air pollution exposure, and iv) inflammasome myocardial activation is a novel pathway of heart injury in exposed individuals.

Acknowledgements: This work was supported in part by the NCRR Grant \# P20RRO15583. This work was presented in part at the 2010 FASEB meeting at Anaheim, CA by Rodolfo Villarreal-Calderon.

\section{References}

1. Brook RD, Rajagopalan S, Pope CA 3rd, Brook JR, Bhatnagar A, Diez-Roux AV, Holguin F, Hong Y, Luepker RV, Mittleman MA, Peters A, Siscovick D, Smith SC Jr., Whitsel L, and Kaufman JD. Particulate matter air pollution and cardiovascular disease. An update to the scientific statement from the American Heart Association. Circulation. 121: 2331-2378. 2010. [Medline] [CrossRef]

2. Franchini M, and Mannucci PM. Thrombogenicity and cardiovascular effects of ambient air pollution. Blood. 118: 2405-2412. 2011. [Medline] [CrossRef]

3. Bravo-Alvarez HR, and Torres-Jardón RJ. Air pollution levels and trends in the Mexico city metropolitan area. In: Urban Air Pollution and Forests: Resources at Risk in the Mexico City Air Basin Ecological Studies. M Fenn, L Bauer, T Hernández (eds). Vol 156. Springer-Verlag; New York: 121-159. 2002.

4. Molina LT, Madronich S, Gaffney JS, Apel E, de Foy B, 
Fast J, Ferrare R, Herndon S, Jimenez JL, Lamb B, OsorioVargas AR, Russell P, Schauer JJ, Stevens PS, Volkamer $\mathrm{R}$, and Zavala M. An overview of the MILAGRO 2006 Campaign: Mexico City emissions and their transport and transformation. Atmos Chem Phys. 10: 8697-8760. 2010. [CrossRef]

5. Osornio-Vargas AR, Bonner JC, Alfaro-Moreno E, Martinez L, Garcia-Cuellar C, Ponce-de-Leon-Rosales S, Miranda J, and Rosas I. Proinflammatory and cytotoxic effects of Mexico City air pollution particulate matter in vitro are dependent on particle size and composition. Environ Health Perspect. 111: 1289-1293. 2003. [Medline] [CrossRef]

6. Rosas-Pérez I, Serrano J, Alfaro-Moreno E, Baumgardner D, Garcia-Cuellar C, Martin del campo JM, Raga GB, Castillejos M, Colin RD, and Osornio-Vargas AR. Relations between $\mathrm{PM}_{10}$ composition and cell toxicity: A multivariate and graphical Approach. Chemosphere. 67: 1218-1228. 2007. [Medline]

7. Querol X, Pey J, Minguillón MC, Pérez N, Alastuey A, Viana M, Moreno T, Bernabe RM, Blanco S, Cardenas B, Vega E, Sosa G, Escalona S, Ruiz H, and Artiñano B. PM speciation and sources in Mexico during the MILAGRO-2006 Campaign. Atmos Chem Phys. 8: 111-128. 2008. [CrossRef]

8. Villarreal-Calderon R, Reed W, Keefe S, Herritt L, Brooks $\mathrm{D}$, Torres-Jardón R, and Calderón-Garcidueñas L. Urban air pollution produces up-regulation of myocardial inflammatory genes and dark chocolate provides cardioprotection. Exp Tox Path. 2010 October 5 E Pub.

9. Garantziotis S, Hollingsworth JW, Zaas AK, and Schwartz DA. The effect of toll-like receptors and toll-like receptors genetics in human disease. Ann Rev Med. 59: 343-359. 2008. [Medline] [CrossRef]

10. Panaro MA, Gagliardi N, Saponaro C, Calvello R, Mitolo I, and Cianciulli A. Toll-like receptor 4 mediates LPSinduced release of nitric oxide and tumor necrosis factoralpha by embryonal cardiomyocytes:biological significance and clinical implications in human pathology. Curr Pharm Des.16: 766-774. 2010. [Medline] [CrossRef]

11. SMA Secretaría del Medio Ambiente del Gobierno del Distrito Federal. Dirección General de Gestión de la Calidad del Aire. Sistema de monitoreo Atmosférico de la ciudad de México. Dirección de Monitoreo Atmosférico. 2008. Indicadores 2010. http://www.sma.df.gob.mx/simat2/.

12. Calderón-Segura ME, Gómez-Arroyo S, Villalobos-Pietrini R, Butterworth FM, and Amador-Munoz O. The effects of seasonal weather on the genotoxicity, cytokinetic properties, cytotoxicity and organochemical content of extracts of airborne particulates in Mexico City. Mutat Res. 558: 7-17. 2004. [Medline]

13. Dzepina K, Arey J, Marr L, Worsnop DR, Salcedo D, Zhang Q, Onasch TB, Molina LT, Molina MJ, and Jimenez JL. Detection of particle-phase polycyclic aromatic hydrocarbons in Mexico City using an aerosol mass spectrometer. International Journal of Mass Spectrometry. 263: 152-170. 2007. [CrossRef]

14. Estrada-Garcia T, Cerna JF, Thompson MR, and LópezSaucedo C. Fecal contamination and enterotoxigenic Escherichia coli in street-vended chili sauces in Mexico and its public relevance. Epidemiology and Infection. 129: 223226. 2002. [Medline] [CrossRef]

15. Riveros-Rosas H, Pfeifer GD, Lynam DR, Pedroza JL,
Julian-Sanchez A, Canales O, and Garfias J. Personal exposure to elements in Mexico city air. Sci Total Environ. 198: 79-96. 1997. [Medline] [CrossRef]

16. Stutz A, Golenbock DT, and Latz E. Inflammasomes: too big to miss. J Clin Invest. 119: 3502-3511. 2009. [Medline] [CrossRef]

17. Martinon F, Mayor A, and Tschopp J. The inflammasomes: guardians of the body. Annual Review of Immunology. 27: 229-265. 2009. [Medline] [CrossRef]

18. Martinon F. Signaling by ROS drives inflammasome activation. Eur J Immunol. 40: 616-619. 2010. [Medline] [CrossRef]

19. Yin Y, Yan Y, Jiang X, Mai J, Chen NC, Wang H, and Yang $\mathrm{XF}$. Inflammasomes are differentially expressed in cardiovascular and other tissues. International Journal of Immunopathology and Pharmacology. 22: 311-322. 2009. [Medline]

20. Bryant C, and Fitzgerald KA. Molecular mechanisms involved in inflammasome activation. Trends in Cell Biology. 19: 455-464. 2009. [Medline] [CrossRef]

21. Cassel SL, Eisenbarth SC, Iyer SS, and Sadler JJ. The Nalp3 inflammasome is essential for the development of silicosis. Proc Natl Acad Sci USA. 105: 9035-9040. 2008. [Medline] [CrossRef]

22. Dostert C, Petrilli V, van Bruggen R, Steel C, Mossman BT, and Tschopp J. Innate immune activation through Nalp3 inflammasome sensing of asbestos and silica. Science. 320: 674-677. 2008. [Medline] [CrossRef]

23. Hornung V, Bauernfeind F, Halle A, Samstad EO, and Kono H. Silica crystals and aluminum salts activate the NAP3 inflammasome through phagosomal destabilization. Nat Immunol. 9: 847-856. 2008. [Medline] [CrossRef]

24. Duewell P, Kono H, Rayner KJ, Sirois CM, Vladimer G, Bauernfeind FG, Abela GS, Franchi L, Nunez G, Schnurr M, Espevik T, Lien E, Fitzgerald KA, Rock KL, Moore KJ, Wright SD, Hornung V, and Latz E. NLRP3 inflammasomes are required for atherogenesis and activated by cholesterol crystals. Nature. 464: 1357-1361. 2010. [Medline] [CrossRef]

25. Holland MR, Gibson AA, Kirshner CA, Hicks D, Ludomirsky A, and Singh GK. Intrinsic myoarchitectural differences between the left and right ventricles of fetal human hearts: an ultrasonic backscatter feasibility study. Journal of the American Society of Echocardiography. 22: 170-176. 2009. [Medline] [CrossRef]

26. Tverskaya MS, Sukhoparova VV, Karpova VV, Raksha AP, Kadyrova MK, Abdulkerimova NZ, and Bobrova NA. Pathomorphology of myocardial circulation: comparative study in increased left or right ventricle overload. Bulletin of Experimental Biology and Medicine. 145: 377-381. 2008. [Medline] [CrossRef]

27. Bouthillier L, Vincent R, Goegan P, Adamson IY, Bjarnason S, Stewart M, Guénette J, Potvin M, and Kumarathasan P. Acute effects of inhaled urban particles and ozone: lung morphology, macrophage activity, and plasma endothelin-1. Am J Pathol. 153: 1873-1884. 1998. [Medline] [CrossRef]

28. Kang YJ, Li Y, Zhou Z, Roberts AM, Cai L, Myers SR, Wang L, and Schuchke DA. Elevation of serum endothelins and cardiotoxicity induced by particulate matter $\left(\mathrm{PM}_{2.5}\right)$ in rats with acute myocardial infarction. Cardiovasc Toxicol. 2: 253-261. 2002. [Medline] [CrossRef]

29. Douthwaite JA, Lees DM, and Corder R. A role for in- 
creased mRNA stability in the induction of endothelin-1 synthesis by lipopolysaccharide. Biochem Pharmacol. 66: 589-594. 2003. [Medline] [CrossRef]

30. Murray DB, Gardner JD, Brower GL, and Janicki JS. Endothelin-1 mediates cardiac mast cell degranulation, matrix metalloproteinase activation, and myocardial remodeling in rats. Am J Physiol Heart Circ Physiol. 287: H2295-2299. 2004. [Medline] [CrossRef]

31. Thomson E, Kumarathasan P, Goegan P, Aubin RA, and Vincent R. Differential regulation of the lung endothelin system by urban particulate matter and ozone. Toxicol Sci. 88: 103-113. 2005. [Medline] [CrossRef]

32. Calderón-Garcidueñas L, Vincent R, Mora-Tiscareño A, Franco-Lira M, Henríquez-Roldán C, Garrido-García L, Camacho-Reyes L, Valencia-Salazar G, Paredes R, Romero L, Osnaya N, Villarreal-Calderon R, Torres-Jardón R, Hazucha MJ, and Reed W. Elevated plasma endothelin-1 and pulmonary arterial pressure in children exposed to air pollution. Environ Health Perspect. 115: 1248-1253. 2007. [Medline] [CrossRef]

33. Deacon K, and Knox AJ. Endothelin-1 (ET-1) increases the expression of remodeling genes in vascular smooth muscle through linked calcium and cyclic-adenosine mono-phosphate (CAMP) pathways: role of a phospholipase A2(cPLA2)/cyclo-oxygenase-2 (COX-2)/prostacyclin receptor dependent autocrine loop. J Biol Chem. 285: 2591325927. 2010. [Medline] [CrossRef]

34. Mansart A, Ruff LJ, Arians MP, Ross JJ, Reilly CS, Brown NJ, Kaufman S, and Brookes ZL. Constriction of rat extrasplenic veins to lipopolysaccharide involves endothelin-1. Naunyn Schmiedebergs Arch Pharmacol. 381: 555-562. 2010. [Medline] [CrossRef]

35. Marron K, Wharton J, Sheppard MN, Fagan D, Royston D, Kuhn DM, de Leval MR, Whitehead BF, Anderson RH, and Polak JM. Distribution, morphology, and neurochemistry of endocardial and epicardial nerve terminal arborizations in the human heart. Circulation. 92: 2343-2351. 1995. [Medline]

36. Sola OM, Shi Q, Vernon RB, and Lazzara RR. Cardiac denervation after transmyocardial laser. Ann Thorac Surg. 71: 732. 2001. [Medline]

37. Accord RE, van Suylen RJ, van Brakel TJ, and Maessen JG. Post-mortem histological evaluation of microwave lesions alter epicardial pulmonary vein isolation for atrial fibrillation. Ann Thoracic Surg. 80: 881-887. 2005. [CrossRef]

38. Kulboka A, Lekas R, Veikutis V, Civinskiene G, and Pavilonis A. Changes of cardiac electrophysiological parameters after destruction of pericardial nervous plexi innervating sinoatrial model. Kardiologiia. 45: 11-14. 2005. [Medline]

39. Levick SP, Murray DB, Janicki JS, and Brower GL. Sympathetic nervous system modulation of inflammation and remodeling in the hypertensive heart. Hypertension. 55: 270-276. 2010. [Medline] [CrossRef]

40. Maurer M, Wedemeyer J, Metz M, Piliponsky AM, Weller K, Chatterjea D, Cloutheir DE, Yanagisawa MM, Tsai M, Galli SJ. Mast cells promote homeostasis by limiting endothelin-1-induced toxicity. Nature. 432: 512-516. 2004. [Medline] [CrossRef]

41. Walsh SK, Kane KA, and Wainwright CL. Mast cell degranulation-a mechanism for the anti-arrhythmic effect of endothelin-1? Br J Pharmacol. 157: 716-723. 2009. [Medline] [CrossRef]
42. Eszlári E, Czóbel M, Molnar G, Kaszaki J, Nagy S, and Boros M. Modulation of cardiac contractility through endothelin-1 release and myocardial mast cell degranulation. Acta Physiol Hung. 95: 267-285. 2008. [Medline] [CrossRef]

43. Calderón-Garcidueñas L, Gambling TM, Acuna H, Garcia R, Osnaya N, Monroy S, Villarreal-Calderon A, Carson J, Koren HS, and Devlin RB. Canines as sentinel species for assessing chronic exposures to air pollutants: part 2. Cardiac pathology. Toxicol Sci. 61: 356-367. 2001. [Medline] [CrossRef]

44. Calderón-Garcidueñas L, Solt AC, Henríquez-Roldán C, Torres-Jardón R, Nuse B, Herritt L, Villarreal-Calderon R, Osnaya N, Garcia R, Brooks DM, Gonzalez-Maciel A, Reynoso-Robles R, Delgado-Chavez R, and Reed W. Longterm air pollution exposure is associated with neuroinflammation, an altered innate immune response, disruption of the blood-brain barrier, ultrafine particulate deposition, and accumulation of amyloid beta- 42 and alpha-synuclein in children and young adults. Toxicol Pathol. 36: 289-310. 2008. [Medline] [CrossRef]

45. Cain BS, Meldrum DR, Dinarello CA, Meng X, Joo KS, Banerjee A, and Harken AH. Tumor necrosis factor-alpha and interleukin-1-beta synergistically depress human myocardial function. Critical Care Medicine. 27: 1309-1318. 1999. [Medline] [CrossRef]

46. Hamid T, Gu Y, Ortines RV, Bhattacharya C, Wang G, Xuan YT, and Prabhu SD. Divergent tumor necrosis factor receptor-related remodeling responses in heart failure: role of nuclear factor kappa B and inflammatory activation. Circulation. 119: 1386-1397. 2009. [Medline] [CrossRef]

47. Schulz R, and Heusch G. Tumor necrosis factor-alpha and its receptors 1 and 2. Circulation. 119: 1355-1357. 2009. [Medline] [CrossRef]

48. Schulz R. TNF $\alpha$ in myocardial ischemia/reperfusion: Damage vs. protection. Journal of Molecular and Cell Cardiology. 45: 712-714. 2008. [CrossRef]

49. Chen Y, Ke Q, Yang Y, Rana JS, Tang J, Morgan JP, and Xiao YF. Cardiomyocytes overexpressing TNF-alpha attract migration of embryonic stem cells via activation of p38 and c-Jun amino-terminal kinase. FASEB J. 17: 22312239. 2003. [Medline] [CrossRef]

50. Bao C, Guo J, Lin G, and Hu Z. TNFR gene-modified mesenchymal stem cells attenuate inflammation and cardiac dysfunction following MI. Scandinavian Cardiovascular Journal. 42: 56-62. 2008. [Medline] [CrossRef]

51. Panaro MA, Cianciulli A, Gagliardi N, Mitolo I, Acquafredda A, Cavallo P, and Mitolo V. CD14 major role during lipopolysacchride-induced inflammation in chick embryo cardiomyocytes. Federation European Microbiological Societies Immunology and Medical Microbiology. 53: 35-45. 2008.

52. Fitzgerald KA, Rowe DC, and Golenbock DT. Endotoxin recognition and signal transduction by the TLR4/MD2complex. Microbes and Infection. 6: 1361-1367. 2004. [Medline] [CrossRef]

53. Rudiger A, and Singer M. Mechanisms of sepsis-induced cardiac dysfunction. Critical Care Medicine. 35: 15991608. 2007. [Medline] [CrossRef]

54. Meldrum DR. Tumor necrosis factor in the heart. American Journal of Physiology. 274: R577-R595. 1998/ [Medline]

55. Comstock KL, Krown KA, and Page MT. LPS-induced TNF-alpha release from and apoptosis in rat cardiomyo- 
cytes: obligatory role for CD14 in mediating the LPS response. J Mol Cell Cardiol. 30: 2761-2775. 1998. [Medline] [CrossRef]

56. Smith BJ, Lightfoot SA, Lerner MR, Denson KD, Morgan DL, Hanas JS, Bronze MS, Postier RG, and Brackett DJ. Induction of cardiovascular pathology in a novel model of low-grade chronic inflammation. Cardiovascular Pathology. 18: 1-10. 2009. [Medline] [CrossRef]

57. Lamkanfi M, and Dixit VM. Inflammasomes: guardians of cytosolic sanctity. Immunological Reviews. 227: 95-105. 2009. [Medline] [CrossRef]

58. Golomb E, Nyska A, and Schwalb H. Occult cardiotoxicitytoxic effects on cardiac ischemic tolerance. Toxicologic Pathology. 37: 572-593. 2009. [Medline] [CrossRef]

59. Mountain DJH, Singh M, and Singh K.Interleukin-1 $\beta$ mediated inhibition of the processes of angiogenesis in cardiac microvascular endothelial cells. Life Sciences. 82, 1224-1230. 2008. [Medline] [CrossRef]

60. Hwang MW, Matsumori A, Furukawa Y, Ono Y, Okada M, Iwasaki A, Hara M, Miyamoto T, Touma M, and Sasayama S. Neutralization of IL1 $\beta$ in the acute phase of myocardial infarction promotes the promotion of progression of left ventricular remodeling. Journal of American College of Cardiology. 38: 1546-1553. 2001. [CrossRef]

61. Ono K, Matsumori A, Shioi T, Furukawa Y, and Sasayuma S. Cytokine gene expression after myocardial infarction in rat hearts: possible implication in left ventricular remodeling. Circulation. 98: 149-156. 1998. [Medline]

62. Bujak M, and Frangogiannis NG. The role of IL-1 in the pathogenesis of heart disease. Archivum Immunologiae et Therapiae Experimentalis. 57: 165-176. 2009. [Medline] [CrossRef]

63. Brandenberger C, Clift MJD, Vanhecke D, Mühlfeld C, Stone V, Gehr P, and Rothen-Rutishauser B. Intracellular imaging of nanoparticles: Is it an elemental mistake to believe what you see? Part Fibre Toxicol. 7: 15-20. 2010. [Medline] [CrossRef]

64. Nawrot TS, Perez L, Künzli N, Munters E, and Nemery B. Public Health importance of triggers of myocardial infarction: a comparative risk assessment. Lancet. 377: 732-740. 2011. [Medline] [CrossRef] 